\title{
Rainfall interception by six urban trees in San Juan, Puerto Rico
}

\author{
Christopher J. Nytch ${ }^{1}$ (D) - Elvia J. Meléndez-Ackerman ${ }^{1} \cdot$ María-Eglée Pérez $^{2} \cdot$ Jorge R. Ortiz-Zayas $^{1}$
}

Published online: 12 June 2018

(C) The Author(s) 2018

\begin{abstract}
Rainfall interception is an important part of the urban hydrological cycle. Understanding is limited about the role of urban trees and other vegetation in the interception process. This study quantified interception losses by six trees in the Caribbean coastal city of San Juan, Puerto Rico, three representing a broadleaf evergreen, and three representing a broadleaf deciduous species. Rainfall was partitioned into throughfall for 13 storms to compare the results between tree types. Total rainfall ranged from 2.9 to $72.4 \mathrm{~mm}$, and storm duration spanned $1 \mathrm{~h}$ to several days. Six of the storms analyzed were characterized by maximum hourly intensity rainfall rates categorized as heavy $(>7.6 \mathrm{~mm} / \mathrm{h})$. Strong northeasterly winds brought rain in sustained gusts up to $35 \mathrm{~km} /$ h. Average interception losses totaled $19.7 \%$ for both tree types, $22.7 \%$ for the deciduous trees, and $16.7 \%$ for the evergreen trees. Throughfall exceeded $90 \%$ of total rainfall for each of the six trees on one or more occasions, and heavy intensity storms produced negative interception losses in one individual. The effect of tree type on interception was significant for storms of low and moderate intensity, but not heavy intensity. Differences in interception losses between storms of similar intensity and between the two tree types were influenced by leaf area and wind. Results suggest that individual urban tree canopies function as spatio-temporally dynamic storage reservoirs whose interception capacity can vary as micro-meteorological conditions change. These findings help advance understanding about interception processes in humid tropical urban settings.
\end{abstract}

Keywords Interception $\cdot$ Rainfall intensity $\cdot$ Urban trees $\cdot$ Subtropical $\cdot$ Puerto Rico

\section{Introduction}

Rainfall interception by trees is an important part of the urban hydrological cycle, and the spatial and temporal distribution of the hydrographic curve in cities (Xiao and McPherson 2002; Livesley et al. 2016). Interception processes are regulated by vegetation at multiple scales and in diverse settings (Crockford and Richardson 2000; Llorens and Domingo 2007), but there is limited understanding of this heterogeneity across urban land cover types. The majority of rainfall interception studies have been conducted in rural forest ecosystems

Electronic supplementary material The online version of this article (https://doi.org/10.1007/s11252-018-0768-4) contains supplementary material, which is available to authorized users.

Christopher J. Nytch

chris.nytch@ites.upr.edu

1 Department of Environmental Sciences, University of Puerto Rico-Río Piedras, PO Box 70377, San Juan, PR 00936-8377, USA

2 Department of Mathematics, University of Puerto Rico-Río Piedras, PO Box 70377, San Juan, PR 00936-8377, USA located in arid to tropical climates, with reported annual interception losses ranging from 10 to $50 \%$ of total precipitation (Carlyle-Moses and Gash 2011). Relatively few analyses have investigated interception processes in urban areas and how they alter the timing and distribution of runoff. Nevertheless, urban forest canopies have been reported to intercept storm precipitation (Inkiläinen et al. 2013; Livesley et al. 2014; Xiao and McPherson 2016), with consequent reductions in runoff volumes across the landscape (Wang et al. 2008; Berland and Hopton 2014; Schooling and Carlyle-Moses 2015). Together with other green spaces, urban and peri-urban trees can contribute to avoided flood control costs and lowered flood risk (Zhang et al. 2015; Kim et al. 2016; Livesley et al. 2016).

Studies of urban trees in general have focused on temperate zones (Roy et al. 2012), and experimental interception studies in urban areas are concentrated in northern temperate dry and humid and subtropical dry climates: Xiao et al. (2000a), Xiao and McPherson (2011), and Xiao and McPherson (2016) studied interception losses of urban, open-grown hardwood trees in the Mediterranean climate of central California; GuevaraEscobar et al. (2007) examined canopy interception by a broadleaf evergreen tree in the semi-arid climate of 
Querétaro City in central Mexico's high plateau; Asadian and Weiler (2009) investigated throughfall losses by urban coniferous trees in the cool, humid climate of Vancouver, British Columbia; Livesley et al. (2014) monitored rainfall interception and stemflow by eucalypt street trees in Melbourne, Australia; and Holder and Gibbes (2017) examined differences in rainfall interception among species and their effect on urban hydrology in the semi-arid region of the Colorado Front Range. Rainfall interception studies in rural subtropical and tropical forest settings abound (see Schellekens et al. 1999; Marin et al. 2000; Muoghalu and Johnson 2000; Kumagai et al. 2005; Holwerda et al. 2006; Fan et al. 2014; Chen and Li 2016), highlighting the importance of interception processes in the hydrologic cycle. Yet there is a disproportionate lack of knowledge about interception processes in the urban tropics. One notable exception is a study by Alves et al. (2018) on the interception capacity of nine city trees in Uruaçu, Brazil. In Central America, CalvoAlvarado et al. (2009) conducted a study in the tropical lowlands of Costa Rica. However, few to no urban interception studies have been published for the Caribbean region.

The hydrological cycle of the humid tropics is driven by intense convective precipitation events that are anticipated to increase in response to global climate change (Wohl et al. 2012). Urban centers in the humid tropics are also experiencing burgeoning population growth as people migrate to cities from rural areas (DeFries et al. 2010; Seto et al. 2012). Urbanization processes typically increase the proportion of impervious surfaces that contribute to stormwater runoff (Shuster et al. 2005; Jacobson 2011). This combination of factors will contribute to an increase in the number of urban dwellers living in flood-prone areas in the next few decades (Güneralp et al. 2015). Assessing interception by subtropical and tropical urban trees is essential to broaden the body of knowledge about green infrastructure and urban ecosystem services (e.g., Wang et al. 2008; Jim and Chen 2009; Livesley et al. 2016; Xiao and McPherson 2016). It is also relevant to informing management practices related to stormwater drainage, environmental quality, and sustainability/urban resilience planning for adapting to climate change (Demuzere et al. 2014; Liu et al. 2014; Silvennoinen et al. 2017). For example, numerous cities, including Philadelphia (Philadelphia Water Department 2011), Singapore (Lim and Lu 2016), and Melbourne (Ferguson et al. 2013) have allocated tens of millions of dollars toward greening of their urban environments for the provision of environmental amenities, including alleviating the impacts of excessive stormwater runoff. Additional quantitative analysis about how urban trees interact with rainfall across species, geographic settings, and diverse spatial and temporal scales is necessary to develop strategic and cost effective stormwater management strategies (Berland et al. 2017).

\section{The interception process}

Rainfall interacts with tree crowns, with some droplets passing directly to the ground as free throughfall, or stored on leaf, branch, and bark surfaces. Stored water can later fall as canopy drip and contribute to throughfall, be diverted via branches and trunks to the ground as stemflow, or be intercepted and evaporated back to the atmosphere (Rutter et al. 1975; Xiao et al. 2000b; Carlyle-Moses and Schooling 2015). Intercepted rainfall can be calculated as the difference between total rainfall above the canopy and net precipitation below the canopy following extraction by plant surfaces (Xiao et al. 2000a; David et al. 2006a). There are several factors that determine the quantity of precipitation that is captured through interception processes. These include local and micro-meteorological conditions (e.g., total rainfall amount, rainfall intensity, event duration, storm frequency, air temperature, wind speed and direction, and humidity), which control precipitation inputs as well as the rate of evaporation from the tree canopy; the morphological structure of individual tree canopies (e.g., stem branching patterns and angles, leaf and stem surface area, gap fraction), which influence the volume and timing of withincanopy flow; and the spatial characteristics and structure of trees in a given stand (e.g., species, tree height and canopy dimensions, stem density), which regulates the collective volume and timing of flow within a stand (Crockford and Richardson 2000; Xiao et al. 2000b; Staelens et al. 2008; Xiao and McPherson 2016).

The structural morphology of urban forests and microclimatic conditions can vary from that found in natural forest stands, with consequent effects on interception losses (Xiao et al. 1998, 2000a; Inkiläinen et al. 2013). Many street and park trees are open-grown or isolated, without competition from other vegetation, which may lead to greater amounts of intercepted rainfall by individual trees due to larger canopies (Xiao and McPherson 2002; Schooling and Carlyle-Moses 2015). Broader, exposed crowns are also subjected to higher wind speeds (Xiao et al. 2000a), as well as elevated ambient temperatures typical of urban areas (Zipperer et al. 1997; Shepherd 2006). Together these factors can modify interception volumes through changes in the angle of incidence at which rainfall strikes the canopy (King and Harrison 1998; Xiao et al. 2000a; Carlyle-Moses and Schooling 2015), and increased evaporation (Xiao et al. 2000a; Guevara-Escobar et al. 2007; Asadian and Weiler 2009). Alternatively, municipal maintenance practices such as pruning often reduce crown height and overall leaf area of urban shrubs and trees (Peper et al. 2001a; Stabler 2008; Meléndez-Ackerman et al. 2016). Xiao and McPherson (2002) examined the influence of tree pruning on leaf and stem surface area of urban trees in California's Central Valley and concluded that rainfall interception was diminished in cities where crown raising and thinning were more frequent and intensive. 
Even though available research suggests that canopy interception can occur in city trees located in diverse biomes (Livesley et al. 2014; Schooling and Carlyle-Moses 2015; Alves et al. 2018), the current literature does not adequately consider the range of structural variability among tree species and types, nor the meteorological conditions that predominate in many of the world's largest metropolitan areas. Further field studies of urban interception processes under distinct rainfall conditions and canopy architectures are required (Xiao and McPherson 2016; Alves et al. 2018). This is true at both canopy and stand scales across urban areas in distinct climatic zones (Inkiläinen et al. 2013; Schooling and Carlyle-Moses 2015), including the subtropical and tropical wet life zones. In that context, the goal of this study was to assess the rainfall interception capacity of urban trees in the Caribbean coastal city of San Juan, Puerto Rico. Specific objectives were to (1) quantify interception by six individuals, three of each from two different urban species representing broadleaf evergreen and broadleaf deciduous trees; (2) determine if there was an effect of tree type on the interception results, and (3) interpret the results in the context of other urban vegetation interception studies. The findings offer insights about the interactions between tree canopies and micro-meteorological conditions that affect hydrologic functions in the urban tropics.

\section{Methods}

\section{Study site}

This study was conducted in San Juan, situated in northeastern Puerto Rico $\left(18^{\circ} 27^{\prime} 58^{\prime \prime}\right.$ N, $66^{\circ} 06^{\prime} 20^{\prime \prime}$ W). San Juan is the capital city of Puerto Rico, the smallest of the Greater Antilles islands within the northern Caribbean basin. The city is located within the $67 \mathrm{~km}^{2}$ catchment of the Río Piedras, a highly urbanized watershed (de Jesús-Crespo and Ramírez 2011). Climatic conditions for the region are consistent with the subtropical moist forest life zone (Holdridge 1967). Average yearly rainfall within the basin ranges from $1500 \mathrm{~mm}$ on the coast to $2100 \mathrm{~mm}$ inland, and mean annual temperatures fluctuate between $23.9{ }^{\circ} \mathrm{C}$ in January and $27.2{ }^{\circ} \mathrm{C}$ in August (Webb and Gomez-Gomez 1998). Daytime winds blow from the northeast at speeds of 4.3 to $6.1 \mathrm{~m} / \mathrm{s}$, and at nighttime they prevail from the southeast at 2.2 to $4.8 \mathrm{~m} / \mathrm{s}$ (Lugo et al. 2011). Precipitation abundance and intensity varies considerably on a seasonal basis, with a drier season occurring from January to April, and wetter periods in May and again from August through November (Lugo et al. 2011). During the drier season, many deciduous trees lose a portion of their leaves. Tropical storms and hurricanes are important meteorological phenomena in Puerto Rico and several cyclonic events have impacted the metropolitan area in the last century (Lugo et al. 2011). The spatial and temporal patterns of rainfall distribution over San Juan are complex. A positive trend of increasing rainfall has been observed in the city over the past 50 years, with an intensification in monthly rainfall during the winter months of January and February, which are historically drier, and an increase in severe rainfall episodes (> $78 \mathrm{~mm}$ in $24 \mathrm{~h}$ ) during the spring (April) and summer (June-August) months (Méndez-Lázaro et al. 2014). Ramos González (2014) calculated that $26.4 \%$ of San Juan's area consists of tree cover, representing approximately 3400 ha. Both native and introduced species are abundant and associated with a diversity of land cover and development types (Lima et al. 2013; Brandeis et al. 2014; Staudhammer et al. 2015). The distribution of urban trees and other woody vegetation throughout the city is driven by complex socialecological processes that occur across multiple spatial and temporal scales (Meléndez-Ackerman et al. 2016).

\section{Study design and field measurements}

Six individual trees, three representing Calophyllum antillanum Britt, and three representing Albizia procera (Roxb.) Benth (Fig. 1), were selected within the North Botanical Garden of the University of Puerto Rico-Río Piedras (UPRRP) in San Juan. This sample number is consistent with recent interception studies in the literature; small sample sizes $(n<10)$ have also been reported by Alves et al. (2018) and Livesley et al. (2014). In studies with larger samples, conspecific replicates often do not exceed three individuals (e.g., Schooling and Carlyle-Moses 2015).

The species were chosen because of their occurrence as two of the ten most common trees across the city (Lima et al. 2013; Staudhammer et al. 2015), and their distinct morphological structure. Calophyllum is a medium-sized evergreen tree native to Puerto Rico with a dense, rounded canopy made up of elliptical leaves. Its bark is rough with numerous rhomboidal cracks (Weaver 1990). Albizia is a medium-large deciduous tree, that was introduced to Puerto Rico in the early twentieth Century (Little and Wadsworth 1964). It frequently has multiple outward-spreading stems, and a thin, sparse canopy composed of long, bipinnate leaves with small leaflets. Its bark is smooth and flakes off in thin sheets (Parrotta 1987). Trees of roughly similar leaf area and canopy dimensions were chosen from both species to minimize structural variability of individuals and thereby focus on differences in hydrologic function between tree types. Proximity of the trees to the Botanical Garden security facilities was also taken into consideration, due to the potential for vandalism or burglary of the sampling equipment. Albizia individuals were all isolated, open-grown trees located in the middle of a fallow field. Calophyllum trees were semi-open-grown, aligned together in a northeast-tosouthwest-trending clump near the field's edge. None of the canopies of the Calophyllum trees overlapped or extended higher than the others. However, they did shade each other 
Fig. 1 The two focal species observed in this study. Left: Albizia procera. Right:

Calophyllum antillanum
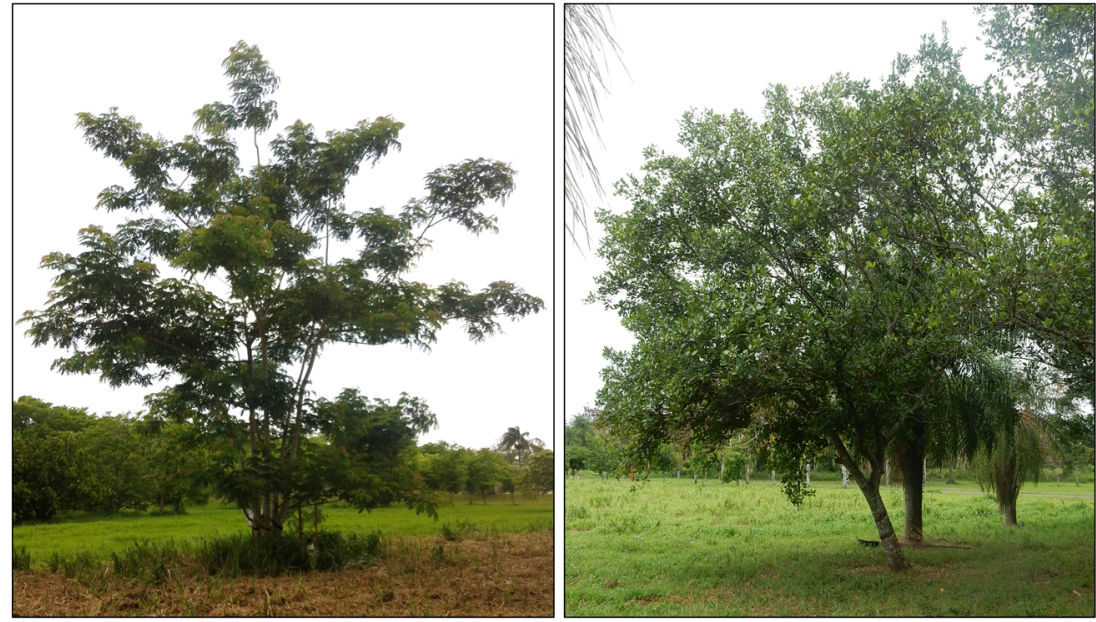

from lateral directions, influencing canopy shape, and potentially blocking wind from one or more directions. All six trees were located on flat land.

Each individual tree was assessed for diameter at breast height (DBH), total height, height to base of live crown, and average crown diameter (two perpendicular dimensions) following methods outlined in Nowak et al. (2001) and the Forest Service Inventory and Analysis National Field Manual (U.S. Department of Agriculture Forest Service 2006). We conducted a search for allometric equations relating DBH and/or crown dimensions to leaf area, using Google Scholar, Scopus, and GlobAllomeTree (an international web platform that shares data for assessing volume, biomass and carbon stock of trees and forest; http://www.globallometree.org/). Leaf area regression equations could not be found for the two focal species. Therefore, we calculated leaf area for the six individuals using predictive allometric equations based on the DBH of structurally similar street trees located in coastal Southern California, as developed by Peper et al. (2001b). The region is part of USDA climate zone 10, which overlaps with Puerto Rico. Albizia leaf area was calculated using the equation for a tree of the same family (Fabaceae), the deciduous Jacaranda mimosifolia. Calophyllum leaf area was calculated using the equation for the broadleaf evergreen Tristania conferta, which has a comparable size and rounded crown with simple leaves. We also considered regression equations developed by Calvo-Alvarado et al. (2008) for several rain forest trees of Costa Rica. However, these were discarded as their growth habit varied substantially from the focal species. The resulting leaf areas were compared against the range of predicted leaf area values reported by Peper et al. (2001b) for the mean DBH of the two reference species.

Canopy throughfall (water passing directly through canopy spaces and dripping off leaves and branches) was measured separately for each tree using HOBO RG3-M (Onset Computer Corporation) tipping bucket rain gauges with Pendant Event automated data loggers. Rain gauges were mounted at a height of $1.37 \mathrm{~m}$ above the ground on treated wooden frames staked to the ground below each tree at a random azimuth $1 \mathrm{~m}$ from the tree bole (Fig. 2). Based on methodology used previously in tropical, temperate, and Mediterranean rainfall interception studies (e.g., Schellekens et al. 1999; Šraj et al. 2008; Asadian and Weiler 2009), two 2-m long aluminum gutters, each with a $4 \mathrm{~cm}$ diameter opening (1600 $\mathrm{cm}^{2}$ surface area total), were hung beneath each tree at a 20-degree angle and used to channel throughfall to the rain gauge. The use of gutters in this manner was intended to capture throughfall from a broader area below the canopy and account for structural attributes of the tree canopies that might lead to both relatively concentrated and deficient canopy drip. The position of the gutters was determined by randomly selecting two perpendicular azimuths from the reference point of the rain gauge, with the condition that the lengths of both gutters were covered completely by the overhanging tree canopy with at least $1 \mathrm{~m}$ of canopy overlap, to prevent rainfall external to the canopy from entering the gutters. The height of the gutters above the ground ranged from $1.5 \mathrm{~m}$ at the lower end to $2.25 \mathrm{~m}$ at the upper end, and the average distance from crown base to gutter was roughly $0.5 \mathrm{~m}$. The lower ends of the gutters were fixed in position to prevent movement and loss of water during windy storms. The top of the wooden frames was tilted slightly to shunt water away from the gutters and not contribute to throughfall overestimation. For a control reference, an additional wooden frame with a single tipping bucket rain gauge and the same arrangement of aluminum gutters to funnel rainfall was erected on the unobstructed rooftop of the nearby Botanical Garden administration building $100 \mathrm{~m}$ to the north and east of the six study trees. Following deployment in the field, all seven rain gauges were calibrated. Rainfall was recorded from August 26 to December 15, 2014. Data were downloaded on a biweekly basis or following large storms using HOBOware Pro software. At each downloading, maintenance was performed to 
A

Individual 1

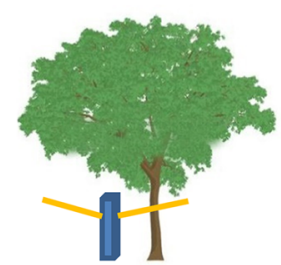

Tree type / canopy structure 1 Individual 2

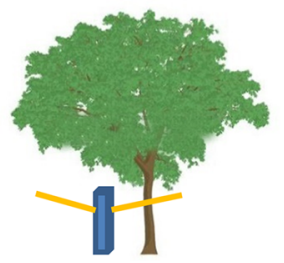

Tree type / canopy structure 2

Individual 1

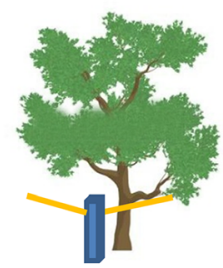

Individual 2

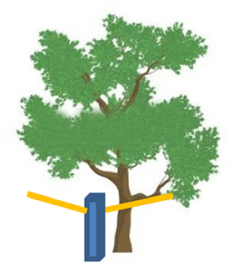

Fig. 2 Study design. a Arrangement of throughfall collectors for six trees from two species of distinct canopy structure, and a rooftop control $\mathbf{b}$. Cartoon of tree type/canopy structure. Type/structure 1 represents the

remove leaves and debris from the gutter channels and logger funnel screen, and relaunch congested loggers blocked with fine particulate matter or ant colonies.

Stemflow was omitted, as it typically represents a small fraction of total annual precipitation (Brooks et al. 2012). In Puerto Rico, previous studies in closed-canopy forest calculated an average stemflow value of $2.3 \%$ total precipitation (Scatena 1990; Schellekens et al. 1999). In Panama, measured values of stemflow in secondary forests range from negligible (Zimmermann et al. 2013) to $1.5 \%$ (Macinnis-Ng et al. 2012) of total precipitation. Urban studies have also calculated stemflow values of less than 5\% (Guevara-Escobar et al. 2007; Xiao and McPherson 2011), although Schooling and Carlyle-Moses (2015) reported a much higher stemflow value of nearly $23 \%$ beneath an individual urban tree during a single storm event.

Data on average storm wind speed, maximum sustained wind speed (sustained for at least two minutes), direction of maximum sustained wind speed, and average relative humidity were retrieved from a micro-meteorological station maintained by the UPRRP Agricultural Experimental Station located $500 \mathrm{~m}$ to the south of the study area, and the National Oceanic and Atmospheric Administration (NOAA) weather station located at the San Juan Luis Muñoz Marín International Airport.

\section{Rainfall partitioning}

Precipitation measurements were recorded during each storm. The tipping bucket rain gauges were designed to

\section{B Control}
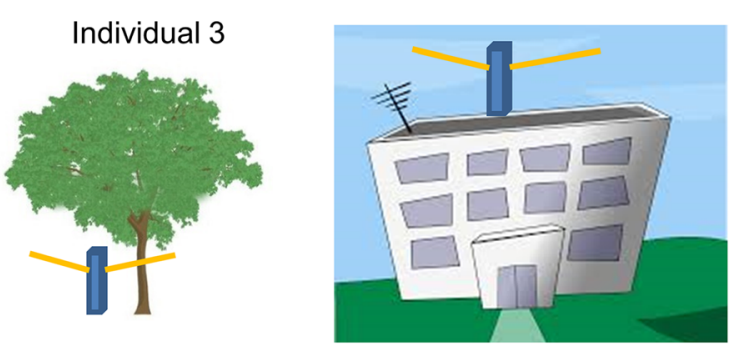

C
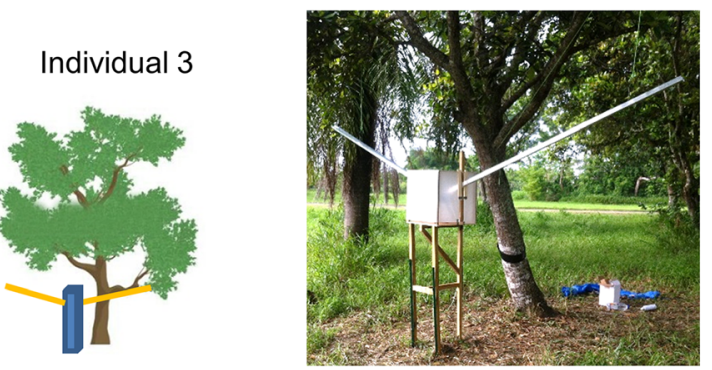

broadleaf evergreen tree $C$. antillanum, while type/structure 2 represents the broadleaf deciduous tree $A$. procera. c Throughfall collector beneath a C. antillanum individual

record rainfall in $0.2 \mathrm{~mm}$ intervals per each tip of the bucket, corresponding to a $182.41 \mathrm{~cm}^{2}$ funnel area. The area of the gutters was approximately 8.8 times larger. Consequently, the recorded data were subsequently converted to reflect this difference in catchment areas, with each click representing approximately $0.02 \mathrm{~mm}$ of rainfall. Furthermore, the maximum converted rainfall rate that the gauges could handle was $14.5 \mathrm{~mm} / \mathrm{h}$. Individual storms were defined as wet periods with a total rainfall minimum of $1 \mathrm{~mm}$ (Asadian and Weiler 2009) separated by dry periods of at least $24 \mathrm{~h}$ (Xiao et al. 2000a) to allow for canopies to regain storage capacity. Each storm contained one or more rainfall events, separated by inter-event rainless periods of at least $4 \mathrm{~h}$ (Xiao et al. 2000a). Duration of storms was calculated as the total time from rainfall onset to cessation as recorded by the control logger. Maximum hourly storm intensity ( $\mathrm{SI}_{\max }$ ) was calculated based on the greatest accumulated rainfall of any $1 \mathrm{~h}$ period during a storm (Zhang et al. 2016). Maximum rainless gap $\left(\mathrm{RG}_{\max }\right)$ was calculated as the greatest span of inter-event time within an individual storm during which the total rainfall was $<0.1 \mathrm{~mm} / \mathrm{h}$, the typical wet-canopy evaporation rate during rainfall (Dunkerley 2015; Zhang et al. 2016). A total of 18 discrete storms were recorded during the study period. A subset of 13 storms was chosen for analysis, corresponding to the availability of throughfall data for all six trees. For each of the selected storms, rainfall was partitioned according to a simplified interception model adapted from Xiao et al. (1998), wherein canopy interception (I) was calculated as the difference between total rainfall (R) and throughfall 
(TH, including free throughfall and drip from leaves and branches).

$\mathrm{I}=\mathrm{R}-\mathrm{TH}$

Rainfall and TH were totaled per individual storms and the entire measurement period, summing consecutive values recorded with temporal separation less than $24 \mathrm{~h}$. Post-storm drip that occurred after the end time of a given storm and prior to the commencing of a subsequent storm was included in the interception total, such that interception loss was calculated following the termination of all TH (Xiao et al. 2000a). Percent throughfall (\% TH) was calculated by dividing throughfall by total rainfall. Total interception percentage (\% I) was determined to be 100 minus percent throughfall. Relative interception losses $\left(\mathrm{I}_{\mathrm{r}}\right)$ were calculated as the ratio of rainfall intercepted over total rainfall.

$\% \mathrm{TH}=\mathrm{TH} / \mathrm{R}$

$\mathrm{I}_{\mathrm{r}}=\mathrm{I} / \mathrm{R}$

\section{Statistical analyses}

Average leaf area was compared between tree type, but sample sizes of three replicate individuals were too small and the method of leaf area assessment too uncertain to determine if there were statistically significant differences. Storm characteristics were totaled for individual storms and over the entire study period. Percent throughfall and $\mathrm{I}_{\mathrm{r}}$ were calculated per each individual tree and per tree type for discrete storms and for the entire study period. Linear models with repeated measures $(n=78)$ were used to evaluate the effects of tree type and $\mathrm{SI}_{\max }$ on $\mathrm{I}_{\mathrm{r}}$ and delay in the onset of TH. Throughfall was not explicitly included because it was implicitly represented by $\mathrm{I}_{\mathrm{r}}$. Exploratory analysis revealed that $\mathrm{R}$ and duration were associated with $\mathrm{SI}_{\max }$, and therefore those variables were not included in the models either. $\mathrm{SI}_{\max }$ was grouped into three categories according to the Federal Meteorological Handbook No. 1 (OFCM 2005): low $(<2.5 \mathrm{~mm} / \mathrm{h})$, $\mathrm{mod}-$ erate $(2.5$ to $7.6 \mathrm{~mm} / \mathrm{h})$, and heavy $(>7.6 \mathrm{~mm} / \mathrm{h})$ ). This threshold for heavy intensity is conservative relative to the value of $78 \mathrm{~mm} / \mathrm{d}$ (equivalent to an average of $3.25 \mathrm{~mm} / \mathrm{h}$ ) reported for severe rainfall events in San Juan by MéndezLázaro et al. (2014). Replicates within tree type were introduced in the models as a block effect, and tree type and $\mathrm{SI}_{\max }$ were introduced as treatment effects, assuming there were no interactions between the blocks and treatments. The $24 \mathrm{~h}$ separation between consecutive storms was assumed to be sufficient time to allow complete canopy drying such that the storms could be considered statistically independent. A correlation matrix was constructed using Spearman's nonparametric rank test to identify relationships between $\mathrm{TH}$ and $\mathrm{SI}_{\max }$ (raw data, not grouped, $n=13$ ), and between $\mathrm{TH}$ and $\mathrm{RG}_{\max }$ for individual trees of each type. Statistical analysis was performed using $\mathrm{R}$ software version 3.3.1 (R Core Team 2016).

\section{Results}

\section{Tree morphology and storm characteristics}

Measured DBH and crown dimensions of the six experimental trees are presented in Table 1. Across all three individuals, Calophyllum had an average DBH of $28.2 \pm 1.5 \mathrm{~m}$, average tree height of $9.7 \pm 0.3 \mathrm{~m}$, average height to crown base distance of $3.1 \pm 0.2 \mathrm{~m}$, average crown diameter of $10.2 \pm 0.3 \mathrm{~m}$, and estimated leaf area of $41.5 \mathrm{~m}^{2} \pm 7.9 \mathrm{~m}$. For Albizia, average DBH was $33.7 \pm 0.7 \mathrm{~m}$, average height tree height was $11.4 \pm 0.4 \mathrm{~m}$, average height to crown base distance was $3.1 \pm$ $0.5 \mathrm{~m}$, average crown diameter was $12.4 \pm 0.2 \mathrm{~m}$, and estimated average leaf area was $78.5 \pm 4.6 \mathrm{~m}^{2}$. The resulting leaf areas calculated for both tree types fell within the $95 \%$ confidence intervals of predicted leaf area reported by Peper et al. (2001b) for the reference species utilized. Although statistical differences in leaf area were not tested for, we observed estimated values and distinct ranges between the two tree types that confirmed their general dissimilarity, with the average leaf area of Albizia being almost double that of Calophyllum.

The selected storms together produced a total rainfall (R) of $317.0 \mathrm{~mm}$ (Table 2). Five of the storms were relatively small, generating less than $7 \mathrm{~mm}$ each. Two relatively large (> $60 \mathrm{~mm}$ ) storms together contributed $40 \%$ of R. The other six storms ranged in depth from 11 to $40 \mathrm{~mm}$. Storm duration was also variable, stretching from approximately 1 to $129 \mathrm{~h}$ (Table 2). Regarding $\mathrm{SI}_{\max }$, two of the storms were of low intensity, five were of moderate intensity, and the remaining six exhibited heavy intensities. Average storm wind speed ranged between 6 and $14 \mathrm{~km} / \mathrm{h}$, with sustained maximum wind gusts between 14 and $35 \mathrm{~km} / \mathrm{h}$, blowing primarily from the northeast (Table 2).

\section{Average interception losses}

For all 13 storms combined, average throughfall of the six trees was $80.4 \pm 18.4 \%$, and average interception was $19.6 \pm$ $18.0 \%$ (Supplemental Table 1). Differences in $\mathrm{I}_{\mathrm{r}}$ were significant across storms $(F=32.45, p<0.001)$. There was a wide span of interception losses across individuals of both tree types, ranging between -21.7 and $79.1 \%$. A general trend of lower interception was observed for storms with greater $\mathrm{R}$ (Fig. 3a). Two of the smallest storms (12 and 13) resulted in relatively high average $I_{r}$ of $60.9 \pm 13.6 \%$ and $40.0 \pm 8.5 \%$, 
Table 1 Descriptive structural characteristics of six urban tree canopies from two species representing broadleaf evergreen and deciduous tree types. Leaf areas were calculated using allometric equations from Peper et al. (2001b)

\begin{tabular}{lrrrrrrrrrr}
\hline & C1* & C2 & C2 & $\begin{array}{l}\text { Mean } \\
\text { C1C2C3 }\end{array}$ & $\begin{array}{l}\text { SD** } \\
\text { C1C2C3 }\end{array}$ & A1* & A2 & $\begin{array}{c}\text { A3 } \\
\text { Mean } \\
\text { A1A2A3 }\end{array}$ & $\begin{array}{l}\text { SD } \\
\text { A1A2A3 }\end{array}$ \\
\hline DBH & 26.2 & 29.8 & 28.6 & 28.2 & 1.5 & 32.7 & 34.5 & 33.9 & 33.7 & 0.7 \\
Tree height (m) & 9.2 & 9.8 & 10.0 & 9.7 & 0.3 & 11.9 & 10.9 & 11.4 & 11.4 & 0.4 \\
Height to crown base (m) & 2.8 & 3.1 & 3.4 & 3.1 & 0.2 & 2.9 & 3.8 & 2.5 & 3.1 & 0.5 \\
Average crown diameter (m) & 10.2 & 10.6 & 9.8 & 10.2 & 0.3 & 12.4 & 12.6 & 12.1 & 12.4 & 0.2 \\
Leaf area $\left(\mathrm{m}^{2}\right)$ & 31.1 & 50.4 & 42.9 & 41.5 & 7.9 & 72.4 & 83.6 & 79.7 & 78.5 & 4.6 \\
\hline
\end{tabular}

${ }^{*} \mathrm{C}=$ Calophyllum antillanum $; \mathrm{A}=$ Albizia procera $; 1,2,3$ refer to individual trees of each species

$* * \mathrm{SD}=$ standard deviation

respectively, across all six trees. In contrast, only $10.3 \pm 6.1 \%$ and $6.4 \pm 14.0 \%$ of $\mathrm{R}$ was intercepted by the trees during the two largest storms (4 and 9). However, these differences in $\mathrm{I}_{\mathrm{r}}$ were not consistent among all small and large storms. During storm 11 when $6.2 \mathrm{~mm}$ of rainfall fell, an average of just 14.2 $\pm 6.0 \%$ was intercepted, while $20.1 \pm 6.3 \%$ of the rainfall was intercepted during the much larger storm $8(R=39.8 \mathrm{~mm})$. The range of $\mathrm{I}_{\mathrm{r}}$ observed among the six individuals also fluctuated between storms. In general, but not exclusively, a broader range of $I_{\mathrm{r}}$ values was observed for storms with $\mathrm{SI}_{\max }$ categorized as low or moderate compared to storms with heavy $\mathrm{SI}_{\max }$ (Fig. 3b). Furthermore, TH exceeded $90 \%$ of R recorded by the control logger for each of the six trees on one or more occasions. Throughfall exceeded $100 \%$ five times for the Calophyllum 3 individual only, resulting in negative $\mathrm{I}_{\mathrm{r}}$ values.

$\mathrm{SI}_{\max }$ (grouped into categories) was a significant factor in determining $\mathrm{I}_{\mathrm{r}}(F=66.70, p<0.001)$, and lower $\mathrm{I}_{\mathrm{r}}$ values were observed for more intense storms (Fig. 3b). Interception proportions less than $10 \%$ frequently occurred for storms with R depths beyond $20 \mathrm{~mm}$ and $\mathrm{SI}_{\max }$ categorized as heavy (Figs. 3a and b). Negative $\mathrm{I}_{\mathrm{r}}$ only occurred for very intense storms with $\mathrm{SI}_{\max } \geq$ $11 \mathrm{~mm} / \mathrm{h}$. Rainfall intensity, as described by $\mathrm{SI}_{\max }$, also had a significant effect on delay in $\mathrm{TH}$ reaching the ground $(F=6.57$, $p<0.01)$. Throughfall delay varied from as little as a few minutes (e.g., storm 1) to several hours (e.g., storm 2), and was similar across individuals within each tree type (Supplemental Table 1). Longer delays occurred for storms that began with light rainfall

Table 2 Characteristics of 13 storms during fall 2014 for which interception dynamics were analyzed

\begin{tabular}{|c|c|c|c|c|c|c|c|c|c|}
\hline Storm & Date & $\begin{array}{l}\text { Duration } \\
\text { (h) }\end{array}$ & $\begin{array}{l}\text { Number } \\
\text { of events }\end{array}$ & $\begin{array}{l}\text { Total rainfall } \\
(\mathrm{mm})\end{array}$ & $\begin{array}{l}\text { Max hourly } \\
\text { intensity } \\
(\mathrm{mm} / \mathrm{h})\end{array}$ & $\begin{array}{l}\text { Max rainless } \\
\text { gap } \\
\text { (h) }\end{array}$ & $\begin{array}{l}\text { Mean wind } \\
\text { speed } \\
(\mathrm{km} / \mathrm{h})\end{array}$ & $\begin{array}{l}\text { Max sustained } \\
\text { wind speed } \\
(\mathrm{km} / \mathrm{h})\end{array}$ & $\begin{array}{l}\text { Max sustained wind } \\
\text { direction (degrees } \\
\text { from north) }\end{array}$ \\
\hline 1 & Sept 9-10 & 25.6 & 2 & 18.6 & 13.7 & 22.3 & 8.9 & 33.8 & 60 \\
\hline 2 & Sept $13-15$ & 51.1 & 4 & 11.2 & 3.3 & 14.8 & 12.4 & 27.4 & 60 \\
\hline 3 & Sept $18-19$ & 30.2 & 2 & 27.9 & 11.1 & 21.1 & 8.5 & 25.7 & 50 \\
\hline 4 & Sept $22-27$ & 128.8 & 8 & 63.6 & 11.4 & 16.5 & 7.1 & 33.8 & 50 \\
\hline 5 & Oct $10-11$ & 25.4 & 2 & 5.9 & 5.2 & 0.2 & 6.6 & 25.7 & 290 \\
\hline 6 & Oct $12-14$ & 23.2 & 5 & 18.9 & 4.4 & 8.4 & 11.7 & 24.1 & 310 \\
\hline 7 & Oct $29-31$ & 61.0 & 4 & 39.7 & 13.3 & 17.6 & 8.9 & 27.4 & 20 \\
\hline 8 & Nov 2-5 & 60.9 & 3 & 39.8 & 13.7 & 14.4 & 8.2 & 35.4 & 50 \\
\hline 9 & Nov 7 & 14.8 & 1 & 72.4 & 10.9 & 0.9 & 11.7 & 25.7 & 80 \\
\hline 10 & Nov 9-10 & 24.0 & 2 & 4.1 & 2.9 & 18.3 & 9.3 & 32.2 & 70 \\
\hline 11 & Nov 11 & 0.9 & 1 & 6.2 & 6.2 & 0.5 & 13.0 & 22.5 & 70 \\
\hline 12 & Nov 14 & 1.3 & 1 & 3.0 & 2.1 & 0.8 & 12.9 & 14.5 & 65 \\
\hline \multirow[t]{6}{*}{13} & Nov $15-17$ & 30.4 & 1 & 5.7 & 1.5 & 15.4 & 14.2 & 35.4 & 60 \\
\hline & Min & 0.9 & 1 & 3.0 & 1.5 & 0.2 & 6.6 & 14.5 & \\
\hline & Max & 128.8 & 8 & 72.4 & 13.7 & 22.3 & 14.2 & 35.4 & \\
\hline & Mean & 36.7 & 3 & 24.4 & 7.7 & 11.6 & 10.3 & 28.0 & \\
\hline & $\mathrm{SD}^{*}$ & 32.3 & 2.0 & 22.3 & 4.6 & 8.0 & 2.4 & 5.8 & \\
\hline & Total & 477.6 & 36 & 317.0 & & & & & \\
\hline
\end{tabular}

* $\mathrm{SD}=$ standard deviation 

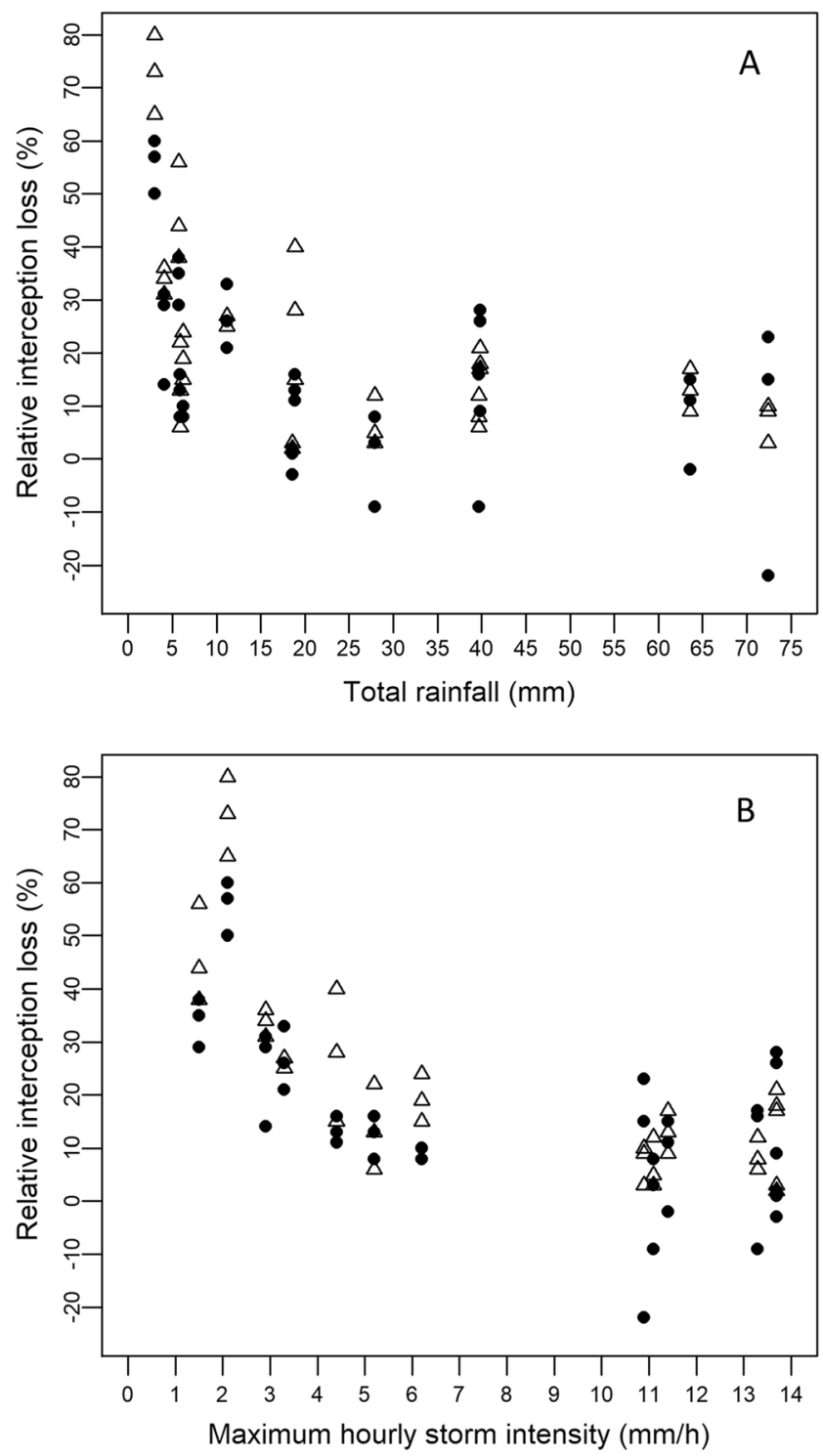

Fig. 3 The relationships between a total rainfall (R) and relative interception loss $\left(\mathrm{I}_{\mathrm{r}}\right)$, and $\mathbf{b}$ maximum hourly storm intensity $\left(\mathrm{SI}_{\max }\right)$ and $\mathrm{I}_{\mathrm{r}}$ for the two tree types. Filled black circles represent C. antillanum; open black triangles represent $A$. procera

followed by a rainless period of several minutes to hours. Percent canopy throughfall $(\% \mathrm{TH})$ was moderately to strongly correlated with $\mathrm{SI}_{\max }$ for the three Calophyllum individuals $(0.52 \leq \rho \leq$ $0.79,0.001 \leq p \leq 0.1$ ), and strongly correlated with $\mathrm{SI}_{\max }$ for the three Albiza individuals $(0.71 \leq \rho \leq 0.82,0.0001 \leq p \leq 0.01)$. Throughfall was not significantly correlated with $\mathrm{RG}_{\max }$ for any of the trees from either type (all $p>0.1$ ).

\section{Interception comparison between tree types}

The average $\mathrm{I}_{\mathrm{r}}$ of the three Calophyllum individuals was 16.4 $\pm 15.9 \%$, while the average $\mathrm{I}_{\mathrm{r}}$ of the three Albizia individuals was $22.8 \pm 19.3 \%$. The proportional difference was not large and both tree types exhibited variability in $I_{r}$, but the effect of tree type was significant $(F=5.56, p<0.05)$. A relatively greater proportion of $\mathrm{R}$ was intercepted by Albizia for storms with $\mathrm{SI}_{\max }$ categorized as low or moderate (e.g., storms 6 and 12). However, post-hoc analysis in which low and moderate intensity storms were removed did not reveal significant differences in $\mathrm{I}_{\mathrm{r}}$ between tree types $(F=0.66, p>0.1)$; i.e., for storms with $\mathrm{SI}_{\max }$ categorized as heavy, the $\mathrm{I}_{\mathrm{r}}$ for Albizia and Calophyllum were statistically similar. Furthermore, the effect of tree type was not important in the onset of TH $(F=0.10$, $p>0.1$, with the Calophyllum and Albizia trees delaying TH by similar amounts of time. Regarding correlations between $\mathrm{SI}_{\max }$ and $\% \mathrm{TH}$, there was no statistical difference in the means for each tree type $(t=1.49, p=0.24)$, but the range of variability was greater for Calophyllum.

\section{Discussion}

\section{Average interception losses}

Many of the results correspond with conclusions reached by other researchers who studied open-grown urban trees. The average interception values of the Albizia and Calophyllum trees are similar to the range of 14 to $27 \%$ reported from central California (Xiao et al. 2000a; Xiao and McPherson 2011), but are lower than the 43 to $48 \%$ interception losses observed in Central Brazil (Alves et al. 2018). They are also much lower than the 59\% interception loss from an urban tree canopy in Central Mexico (Guevara-Escobar et al. 2007), and the 49 to $61 \%$ interception losses from temperate conifers in Coastal British Columbia (Asadian and Weiler 2009). Differences in rainfall conditions, climate (evaporation in Mexico's high plateau was not limited due to low relative humidity and elevated temperatures) and tree canopy structure (the trees sampled in British Columbia were coniferous evergreens) probably account for some of these discrepancies.

The high throughfall proportions that were observed in all individuals of both evergreen and deciduous types, and consistently under heavy rainfall conditions, suggests that rainfall amount and intensity were the dominant factors influencing interception values in our study. Our findings concur with numerous studies that have quantified the linkages between interception capacity and total precipitation and rainfall rate (e.g., Domingo et al. 1998; Xiao et al. 2000a, b; GuevaraEscobar et al. 2007; Šraj et al. 2008; Staelens et al. 2008; Alves et al. 2018). Greater interception losses frequently occur in response to smaller, less intense storms; this can be explained by high canopy storage capacity that retains the small volume of water on the crown surface (Xiao et al. 2000b; Staelens et al. 2008; Xiao and McPherson 2016). In contrast, as canopies become saturated, surface storage capacity decreases and throughfall and canopy drip increase (Xiao et al. 2000b; Keim et al. 2006). This is particularly prominent in 
tropical settings with heavy rainfall events (Crockford and Richardson 2000). Alves et al. (2018) reported average interception of $40 \%$ for urban rainfall of short duration and intensity, in contrast with $3.6 \%$ interception for the most intense and long-lasting events. In another study in the Amazon rainforest, almost $30 \%$ of measured throughfall exceeded total precipitation (Lloyd and Marques 1988).

Yet average interception losses were not always comparable for storms of similar size, and negative values were only reported for one tree. What mechanistic factors contributed to the observed differences? It is common for stored moisture to remain on leaf surfaces from one storm to the next and affect storage capacity (Xiao et al. 2000b). However, stored moisture was probably not a major factor in this study, due to the $24 \mathrm{~h}$ dry period used to separate storms. Rather, wind likely played a key role. Strong gusts of wind can lead to both underestimation of total rainfall and contribute additional precipitation from lateral directions (Manokaran 1979; Crockford and Richardson 2000; Van Stan et al. 2011). In our study, there were sustained gusts of intense wind during all storms, which could have affected the totals recorded by the loggers. Wind may have been particularly important during the five heavy intensity storms where negative interception values were observed in Calophyllum 3. This individual was situated on the edge of a loose clump of trees of the same species. Thus, its spatial position - exposed on one side to the winds that blew predominantly from the northeast - may have contributed to it receiving and retaining more direct rainfall, while partially blocking rain from reaching the other Calophyllum trees located downwind. Results from other studies have demonstrated that wind can affect the angle of incidence at which rainfall strikes more open-grown tree canopies and change the distribution of throughfall and stemflow (King and Harrison 1998; Xiao et al. 2000a). Specifically, wind-driven rainfall at inclination angles of up to $45^{\circ}$ from the vertical tends to concentrate on the upwind side and increase throughfall beneath that portion of the crown, while generating downwind rainshadows that can extend for several meters (David et al. 2006b; Van Stan et al. 2011). High wind speeds can also increase crown drip that contributes to throughfall (Šraj et al. 2008). Another possible explanation for the observed negative interception values in Calophyllum 3 is that the collection gutters were situated below canopy drip points, which can result in throughfall values that exceed total precipitation amounts (Bruijnzeel 2001; Chang 2006). Šraj et al. (2008), for example, attributed concentration from such drip points to higher throughfall values in forest trees in Slovenia.

\section{Interception comparison between tree types}

The relatively higher $\mathrm{I}_{\mathrm{r}}$ values observed for Albizia during storms categorized as low and moderate $\mathrm{SI}_{\max }$ were substantial enough to result in a significant interception difference between the two tree types. Multiple urban studies have shown that rainfall interception can differ between species because of variability in leaf area. For example, Xiao and McPherson (2002), Xiao and McPherson (2011), and Xiao and McPherson (2016) documented leaf surface area as contributing to differences in interception capacities between broadleaf evergreen, broadleaf deciduous, and coniferous trees. Livesley et al. (2014) compared urban canopy throughfall below two eucalyptus individuals from distinct species and with variable plant area indices, and found that total annual interception was greater for the species with denser canopy. Alves et al. (2018) likewise confirmed increased interception by urban trees with greater leaf area, and Holder and Gibbes (2017) identified a positive relationship between woody area to leaf area ratio and canopy surface storage that varied among urban species. In our study, the tree type with the larger average leaf area also exhibited a greater capacity to intercept rainfall. However, it is important to reiterate that the difference in leaf area between trees was not statistically evaluated due to a small sample size. Furthermore, the logarithmic regression equations used were proxies based on assumptions about structural similarities between tree types. Even when applied to trees for which they were specifically developed, regression models are more weakly correlated to true leaf area than sophisticated approaches using hemispherical photography (Peper and McPherson 2003). Therefore, the observed differences in leaf area should be interpreted with caution.

Variability in internal canopy architecture between tree types is possible as well. More specifically, canopy gaps/leaf area, leaf shape, orientation and surface roughness, branch and trunk angle, flow path obstructions and their size/position along branches, bark type and thickness can all affect throughfall yield (Crockford and Richardson 2000; Xiao et al. 2000b; Keim et al. 2006; Brooks et al. 2012; Van Stan et al. 2015; Xiao and McPherson 2016). Detailed branching structure was not evaluated in this study, but there were quantitative differences between the two tree types monitored. The Albizia crowns were on average about $2 \mathrm{~m}$ taller (Table 1) than the Calophyllum crowns. Large gaps between branches were also present in the canopies of the Albizia trees while the Calophyllum canopies were rounded (Fig. 1). This variability likely led to heterogeneous patterns of canopy saturation and interception, which is reflected in the slightly lower correlation values between $\mathrm{SI}_{\max }$ and \% $\mathrm{TH}$ observed among the Calophyllum individuals. Denser canopies can capture greater amounts of rainfall in windy conditions (Van Stan et al. 2011), and projecting crowns with gaps increase the evaporation rate of intercepted water (Crockford and Richardson 2000; Sraj et al. 2008). Furthermore, differences between tree types could have been compounded by canopy drip points that augmented throughfall (Chang 2006; Šraj et al. 2008).

Modeling and field experiments have also demonstrated that interception capacity is influenced by evaporation (Huang et al. 2017), and the removal of surface water from 
canopies by wind (Crockford and Richardson 2000; GuevaraEscobar et al. 2007; Xiao and McPherson 2016). The effect of evaporation is especially prominent during extensive interevent periods without rainfall in arid environments (Zhang et al. 2016). Evaporation is not as crucial in humid subtropical environments dominated by intense storms (Brooks et al. 2012), like San Juan. Still, the three Albizia individuals were open-grown and well exposed to wind from all sides, whereas the three Calophyllum were flanking one another. Even if evaporative drying was not a major factor contributing to large reductions in throughfall overall, it could have led to greater interception in the Albizia trees.

This leads us to conclude that both storm dynamics and structural morphology interacted simultaneously to influence interception outcomes. During smaller, less intense storms, differences between tree types persisted. However, when low and moderate intensity storms were removed and the interception responses to storms with heavy $\mathrm{SI}_{\max }$ values were analyzed alone, the differences disappeared. Therefore, the hydrologic outcomes of differences in canopy structure can be complex; structural variability may be sufficient to elicit functional disparities between individuals of dissimilar tree types under some storm conditions but not others. Had we only looked at a single individual of each tree species or compared storms of similar magnitude, it is possible we would have missed this interception heterogeneity.

Seasonal changes in phenology, such as the loss of deciduous leaves, could further accentuate interception differences between species. Xiao and McPherson (2002) investigated seasonal interception capacities of six tree species in Santa Monica, California in response to cumulative annual rainfall and discrete summer and winter events. Results showed that annual rainfall interception varied widely among tree species and sizes, but generally increased with longer foliation period and greater leaf surface area; average summer interception losses were $47 \%$ versus winter rainfall interception losses of 16\%. Xiao and McPherson (2011) also observed a doubling in the percentage of rainfall intercepted from winter to summer events, owing to increased surface moisture storage associated with greater summer leaf area indices. Similar seasonal differences may likewise be at work in the urban tropics. Additional investigation is needed in San Juan to quantify the effects of season on canopy leaf area for deciduous vs. evergreen trees, and the resulting impact on interception capacity.

\section{Conclusion}

Our study advances understanding of interception processes by trees in the urban tropics and provides a much-needed data point for the Caribbean region. The findings underscore that the interception capacities of individual urban trees can be functionally diverse and spatio-temporally dynamic, in accordance with structural canopy attributes and micrometeorological conditions. During relatively small and less intense storms, the canopies of the six trees we examined influenced throughfall, the magnitudes of which varied by tree type and individual. However, interception capacity was severely limited during larger and more intense storms, regardless of tree type. These factors, along with tree cover, soil hydrologic groups, infiltration, storage, and other variables must be taken into consideration when developing strategies for managing stormwater flows, particularly in geographic locations where climate change is anticipated to increase rainfall intensity. Further evaluation of more individuals representing multiple species distributed across the urban landscape is necessary to determine the implications of these findings for watershed level runoff and flooding processes at the city scale.

Acknowledgements This material is based on work supported by the National Science Foundation under grant number 0801577, and the Garden Club of America Zone VI 2014 and 2015 Urban Forestry Fellowships. Juan Miguel Ortíz provided authorization to study trees in the University of Puerto Rico Botanical Garden. Fieldwork was conducted with the aid of Leticia Classen, José Pérez, Joel Montañez, Lelis Figueroa, and Aaron Hogan. William Shuster, Laura Shifman, Molly Ramsey, Sofia Olivero Lora, and Mervin Pérez provided comments that improved the quality of this manuscript. The authors also appreciate the editorial comments provided by four anonymous reviewers.

Author contributions C.J. Nytch conceived and developed the study design, with input from E.J. Meléndez-Ackerman and J.R. Ortíz-Zayas. C.J.N. collected and analyzed the data, assisted by E.J.M and M.E. Pérez. C.J.N developed the organizational layout of the manuscript and prepared the text, tables, and figures. E.J.M, M.E.P, and J.R.O. helped edit the manuscript for content and language. All authors have read and approved the final version.

Funding This material is based on work supported by the National Science Foundation under grant number 0801577, and the Garden Club of America Zone VI 2014 and 2015 Urban Forestry Fellowships.

\section{Compliance with ethical standards}

Conflict of interest The authors declare that they have no conflict of interest.

Open Access This article is distributed under the terms of the Creative Commons Attribution 4.0 International License (http:// creativecommons.org/licenses/by/4.0/), which permits unrestricted use, distribution, and reproduction in any medium, provided you give appropriate credit to the original author(s) and the source, provide a link to the Creative Commons license, and indicate if changes were made.

\section{References}

Alves PL, Formiga KTM, Traldi MAB (2018) Rainfall interception capacity of tree species used in urban afforestation. Urban Ecosyst. https://doi.org/10.1007/s11252-018-0753-y

Asadian Y, Weiler M (2009) A new approach in measuring rainfall interception by urban trees in coastal British Columbia. Water Qual Res J Canada 44:16-25 
Berland A, Hopton ME (2014) Comparing street tree assemblages and associated stormwater benefits among communities in metropolitan Cincinnati, Ohio, USA. Urban For Urban Green 13:734-741

Berland A, Shiflett SA, Shuster WD, Garmestani AS, Goddard HC, Herrmann DL, Hopton ME (2017) The role of trees in urban stormwater management. Landsc Urban Plan 162:167-177

Brandeis TJ, Escobedo FJ, Staudhammer CL, et al (2014) San Juan Bay Estuary Watershed Urban Forest Inventory. USDA Forest Service Southern Research Station, General Technical Report SRS190. https://www.nrs.fs.fed.us/pubs/45759. Accessed 28 Mar 2014

Brooks KN, Ffolliott PF, Magner JA (2012) Hydrology and the Management of Watersheds. John Wiley \& Sons, Ames

Bruijnzeel LA (2001) Forest hydrology. In: Evans J (ed) The forests handbook, volume 1: An Overview of Forest Science. Blackwell Science, Ltd, Oxford, p 56-78

Calvo-Alvarado J, Jimenez-Rodriguez C, Carvajal-Vanegas D, AriasAguilar D (2009) Rainfall interception in tropical forest ecosystems: treeplantations and secondary forest. In: 2009 Virginia Water Research Conference. Presented at the Water Resources in Changing Climates. Virginia Tech, Virginia, pp 74-83

Calvo-Alvarado JC, McDowell NG, Waring RH (2008) Allometric relationships predicting foliar biomass and leaf area: sapwood area ratio from tree height in five Costa Rican rain forest species. Tree Physiol 28:1601-1608

Carlyle-Moses DE, Gash JHC (2011) Rainfall interception loss by forest canopies. In: Levia D, Carlyle-Moses D, Tanaka T (eds) Forest Hydrology and Biogeochemistry: Synthesis of Past Research and Future Directions. Springer, New York, pp 407-423

Carlyle-Moses DE, Schooling JT (2015) Tree traits and meteorological factors influencing the initiation and rate of stemflow from isolated deciduous trees. Hydrol Process 29:4083-4099

Chang M (2006) Forest hydrology: an introduction to water and forests. CRC press, Boca Raton

Chen Y-Y, Li M-H (2016) Quantifying rainfall interception loss of a subtropical broadleaved forest in Central Taiwan. Water 8:14

Crockford RH, Richardson DP (2000) Partitioning of rainfall into throughfall, stemflow and interception: effect of forest type, ground cover and climate. Hydrol Process 14:2903-2920

David JS, Valente F, Gash JH (2006a) Evaporation of intercepted rainfall. Encycl Hydrol Sci. https://doi.org/10.1002/0470848944.hsa046

David TS, Gash JHC, Valente F, Pereira JS, Ferreira MI, David JS (2006b) Rainfall interception by an isolated evergreen oak tree in a Mediterranean savannah. Hydrol Process 20:2713-2726

de Jesús-Crespo R, Ramírez A (2011) Effects of urbanization on stream physicochemistry and macroinvertebrate assemblages in a tropical urban watershed in Puerto Rico. J N Amer Benthol Soc 30:739-750

DeFries RS, Rudel T, Uriarte M, Hansen M (2010) Deforestation driven by urban population growth and agricultural trade in the twenty-first century. Nat Geosci 3:178-181

Demuzere M, Orru K, Heidrich O, Olazabal E, Geneletti D, Orru H, Bhave AG, Mittal N, Feliu E, Faehnle M (2014) Mitigating and adapting to climate change: multi-functional and multi-scale assessment of green urban infrastructure. J Environ Manag 146:107-115

Domingo F, Sánchez G, Moro MJ, Brenner AJ, Puigdefábregas J (1998) Measurement and modelling of rainfall interception by three semiarid canopies. Agric For Meteorol 91:275-292

Dunkerley D (2015) Intra-event intermittency of rainfall: an analysis of the metrics of rain and no-rain periods. Hydrol Process 29:3294-3305

Fan J, Oestergaard KT, Guyot A, Lockington DA (2014) Measuring and modeling rainfall interception losses by a native Banksia woodland and an exotic pine plantation in subtropical coastal Australia. J Hydrol 515:156-165

Ferguson BC, Brown RR, Frantzeskaki N, de Haan FJ, Deletic A (2013) The enabling institutional context for integrated water management: lessons from Melbourne. Water Res 47:7300-7314
Guevara-Escobar A, González-Sosa E, Véliz-Chávez C, Ventura-Ramos E, Ramos-Salinas M (2007) Rainfall interception and distribution patterns of gross precipitation around an isolated Ficus benjamina tree in an urban area. J Hydrol 333:532-541

Güneralp B, Güneralp İ, Liu Y (2015) Changing global patterns of urban exposure to flood and drought hazards. Glob Environ Chang 31: $217-225$

Holder CD, Gibbes C (2017) Influence of leaf and canopy characteristics on rainfall interception and urban hydrology. Hydrol Sci J 62:182190

Holdridge LR (1967) Life Zone Ecology. Tropical Science Center, San José, Costa Rica

Holwerda F, Scatena FN, Bruijnzeel LA (2006) Throughfall in a Puerto Rican lower montane rain forest: a comparison of sampling strategies. J Hydrol 327:592-602

Huang JY, Black TA, Jassal RS, Les LLM (2017) Modelling rainfall interception by urban trees. Can Water Resour J 42:336-348

Inkiläinen ENM, McHale MR, Blank GB et al (2013) The role of the residential urban forest in regulating throughfall: a case study in Raleigh, North Carolina, USA. Landsc Urban Plan 119:91-103

Jacobson CR (2011) Identification and quantification of the hydrological impacts of imperviousness in urban catchments: a review. J Environ Manag 92:1438-1448

Jim CY, Chen WY (2009) Ecosystem services and valuation of urban forests in China. Cities 26:187-194

Keim RF, Skaugset AE, Weiler M (2006) Storage of water on vegetation under simulated rainfall of varying intensity. Adv Water Resour 29: 974-986

Kim H, Lee D-K, Sung S (2016) Effect of urban green spaces and flooded area type on flooding probability. Sustainability 8:134

King BP, Harrison SJ (1998) Throughfall patterns under an isolated oak tree. Weather 53:111-121

Kumagai T, Saitoh TM, Sato Y et al (2005) Annual water balance and seasonality of evapotranspiration in a Bornean tropical rainforest. Agric For Meteorol 128:81-92

Lim HS, Lu XX (2016) Sustainable urban stormwater management in the tropics: an evaluation of Singapore's ABC waters program. J Hydrol 538:842-862

Lima JMT, Staudhammer CL, Brandeis TJ et al (2013) Temporal dynamics of a subtropical urban forest in San Juan, Puerto Rico, 20012010. Landsc Urban Plan 120:96-106

Little EL, Wadsworth FH (1964) Common trees of Puerto Rico and the Virgin Islands. US Department of Agriculture, Handbook No. 249. Washington, DC.

Liu W, Chen W, Peng C (2014) Assessing the effectiveness of green infrastructures on urban flooding reduction: a community scale study. Ecol Model 291:6-14

Livesley SJ, Baudinette B, Glover D (2014) Rainfall interception and stem flow by eucalypt street trees-the impacts of canopy density and bark type. Urban For Urban Green 13:192-197

Livesley SJ, McPherson GM, Calfapietra C (2016) The urban forest and ecosystem services: impacts on urban water, heat, and pollution cycles at the tree, street, and city scale. J Environ Qual 45:119-124

Llorens P, Domingo F (2007) Rainfall partitioning by vegetation under Mediterranean conditions. A review of studies in Europe. J Hydrol 335:37-54

Lloyd CR, Marques A de O (1988) Spatial variability of throughfall and stemflow measurements in Amazonian rainforest. Agric For Meteorol 42:63-73

Lugo AE, González OMR, Pedraza CR (2011) The Río Piedras Watershed and its surrounding environment. FS-980. U.S. Department of Agriculture, Forest Service. International Institute of Tropical Forestry. San Juan, Puerto Rico. https://www.fs.fed.us/ global/iitf/pubs/RioPiedras_FNLrvsd.pdf. Accessed 2 Sept 2012

Macinnis-Ng CMO, Flores EE, Müller H, Schwendenmann L (2012) Rainfall partitioning into throughfall and stemflow and associated 
nutrient fluxes: land use impacts in a lower montane tropical region of Panama. Biogeochemistry 111:661-676

Manokaran N (1979) Stemflow, throughfall and rainfall interception in a lowland tropical rain forest in Peninsular Malaysia. Malays For 42: 174-201

Marin CT, Bouten W, Sevink J (2000) Gross rainfall and its partitioning into throughfall, stemflow and evaporation of intercepted water in four forest ecosystems in western Amazonia. J Hydrol 237:40-57

Meléndez-Ackerman EJ, Nytch CJ, Santiago-Acevedo LE, Verdejo-Ortiz J, Santiago-Bartolomei R, Ramos-Santiago L, Muñoz-Erickson T (2016) Synthesis of household yard area dynamics in the city of San Juan using multi-scalar social-ecological perspectives. Sustain 8. https://doi.org/10.3390/su8050481

Méndez-Lázaro PA, Nieves-Santiango A, Miranda-Bermúdez J (2014) Trends in total rainfall, heavy rain events, and number of dry days in San Juan, Puerto Rico, 1955-2009. Ecol Soc 19:50

Muoghalu JI, Johnson SO (2000) Interception, $\mathrm{pH}$ and solid content of rainfall in a Nigerian lowland rain forest. Afr J Ecol 38:38-46

Nowak DJ, Crane DE, Steven JC (2001) The urban Forest effects (UFORE) model: field data collection procedures. U.S. Department of Agriculture Forest Service, Northeastern Research Station., Syracuse, p 51

OFCM (2005) Surface Weather Observations and Reports. NOAA/Office of the Federal Coordinator for Meteorological Services and Supporting Research, Washington, DC

Parrotta JA (1987) Albizia procera (Roxb.) Benth. Silvics of Forest Trees of the American Tropics. USDA Forest Service. International Institute of Tropical Forestry, Rio Piedras

Peper PJ, McPherson EG (2003) Evaluation of four methods for estimating leaf area of isolated trees. Urban For Urban Green 2:19-29

Peper PJ, McPherson EG, Mori SM (2001a) Equations for predicting diameter, height, crown width, and leaf area of San Joaquin Valley street trees. J Arboric 27:306-317

Peper PJ, McPherson EG, Mori SM (2001b) Predictive equations for dimensions and leaf area of coastal Southern California street trees. J Arboric 27:169

Philadelphia Water Department (2011) Green Cities, Clean Water: The City of Philadelphia's Program for Combined Sewer Overflow Control. Philadelphia, PA. http://www.phillywatersheds.org/doc/ GCCW_AmendedJune2011_LOWRES-web.pdf

R Core Team (2016) R: A language and environment for statistical computing. R Foundation for Statistical Computing, Vienna, Austria. URL http://www.R-project.org/. June 2016

Ramos-González OM (2014) The green areas of San Juan, Puerto Rico. Ecol Soc 19:21

Roy S, Byrne J, Pickering C (2012) A systematic quantitative review of urban tree benefits, costs, and assessment methods across cities in different climatic zones. Urban For Urban Green 11:351-363

Rutter AJ, Morton AJ, Robins PC (1975) A predictive model of rainfall interception in forests. II. Generalization of the model and comparison with observations in some coniferous and hardwood stands. J Appl Ecol 12:367-380

Scatena FN (1990) Watershed scale rainfall interception on two forested watersheds in the Luquillo Mountains of Puerto Rico. J Hydrol 113: 89-102

Schellekens J, Scatena FN, Bruijnzeel LA, Wickel AJ (1999) Modelling rainfall interception by a lowland tropical rain forest in northeastern Puerto Rico. J Hydrol 225:168-184

Schooling JT, Carlyle-Moses DE (2015) The influence of rainfall depth class and deciduous tree traits on stemflow production in an urban park. Urban Ecosyst 18:1261-1284

Seto KC, Güneralp B, Hutyra LR (2012) Global forecasts of urban expansion to 2030 and direct impacts on biodiversity and carbon pools. Proc Natl Acad Sci 109:16083-16088

Shepherd JM (2006) Evidence of urban-induced precipitation variability in arid climate regimes. J Arid Environ 67:607-628
Shuster WD, Bonta J, Thurston H, Warnemuende E, Smith DR (2005) Impacts of impervious surface on watershed hydrology: a review. Urban Water J 2:263-275

Silvennoinen S, Taka M, Yli-Pelkonen V, Koivusalo H, Ollikainen M, Setälä H (2017) Monetary value of urban green space as an ecosystem service provider: a case study of urban runoff management in Finland. Ecosyst Serv 28:17-27

Šraj M, Brilly M, Mikoš M (2008) Rainfall interception by two deciduous Mediterranean forests of contrasting stature in Slovenia. Agric For Meteorol 148:121-134

Stabler LB (2008) Management regimes affect woody plant productivity and water use efficiency in an urban desert ecosystem. Urban Ecosyst 11:197-211

Staelens J, De Schrijver A, Verheyen K, Verhoest NEC (2008) Rainfall partitioning into throughfall, stemflow, and interception within a single beech (Fagus sylvatica L.) canopy: influence of foliation, rain event characteristics, and meteorology. Hydrol Process 22:33-45

Staudhammer CL, Escobedo FJ, Holt N, Young LJ, Brandeis TJ, Zipperer W (2015) Predictors, spatial distribution, and occurrence of woody invasive plants in subtropical urban ecosystems. J Environ Manag 155:97-105

U.S. Department of Agriculture Forest Service (2006) Forest inventory and analysis national field manual. Urban inventory pilot supplement. Section 15. Urban Measurements and Sampling. Knoxville, TN: U.S. Department of Agriculture Forest Service Forest Inventory and Analysis Program 68 p. http://www.fia.fs.fed.us/library/fieldguides-methods-proc/docs/core_ver_4-0_10_2007_p2.pdf

Van Stan JT, Levia DF Jr, Jenkins RB (2015) Forest canopy interception loss across temporal scales: implications for urban greening initiatives. Prof Geogr 67:41-51

Van Stan JT, Siegert CM, Levia DF Jr, Scheick CE (2011) Effects of wind-driven rainfall on stemflow generation between codominant tree species with differing crown characteristics. Agric For Meteorol 151:1277-1286

Wang J, Endreny TA, Nowak DJ (2008) Mechanistic simulation of tree effects in an urban water balance model. J Am Water Resour Assoc 44:75-85

Weaver PL (1990) Calophyllum calaba L. María, santa-maria. Silvics North Am 2:172

Webb RMT, Gomez-Gomez F (1998) Synoptic survey of water quality and bottom sediments, San Juan Bay estuary system, Puerto Rico, December 1994-July 1995. US Geol Surv Water Resour Investig Rep 97-4144, San Juan, Puerto Rico

Wohl E, Barros A, Brunsell N, Chappell NA, Coe M, Giambelluca T, Goldsmith S, Harmon R, Hendrickx JMH, Juvik J, McDonnell J, Ogden F (2012) The hydrology of the humid tropics. Nat Clim Chang 2:655-662

Xiao Q, McPherson E (2002) Rainfall interception by Santa Monica's municipal urban forest. Urban Ecosyst 6:291-302

Xiao Q, McPherson E, Simpson J, Ustin S (1998) Rainfall interception by Sacramento's urban forest. J Arboric 24:235-244

Xiao Q, McPherson EG (2016) Surface water storage capacity of twenty tree species in Davis, California. J Environ Qual 45:188-198

Xiao Q, McPherson EG (2011) Rainfall interception of three trees in Oakland, California. Urban Ecosyst 14:755-769

Xiao Q, McPherson EG, Ustin SL, Grismer ME, Simpson JR (2000a) Winter rainfall interception by two mature open-grown trees in Davis, California. Hydrol Process 14:763-784

Xiao Q, McPherson EG, Ustin SL, Grismer ME (2000b) A new approach to modeling tree rainfall interception. J Geophys Res Atmos 105: 29173-29188

Zhang B, Li N, Wang S (2015) Effect of urban green space changes on the role of rainwater runoff reduction in Beijing, China. Landsc Urban Plan 140:8-16

Zhang Z-S, Zhao Y, Li X-R, Huang L, Tan H-J (2016) Gross rainfall amount and maximum rainfall intensity in 60-minute influence on 
interception loss of shrubs: a 10-year observation in the Tengger Desert. Sci Rep 6:26030

Zimmermann B, Zimmermann A, Scheckenbach HL, Schmid T, Hall JS, van Breugel M (2013) Changes in rainfall interception along a secondary forest succession gradient in lowland Panama. Hydrol Earth Syst Sci 17:4659-4670

Zipperer WC, Sisinni SM, Pouyat RV, Foresman TW (1997) Urban tree cover: an ecological perspective. Urban Ecosyst 1:229-246 